\title{
Accumulation of Proline under Salinity and Heavy metal stress in Cauliflower seedlings
}

\section{${ }^{* 1}$ THERIAPPAN, P; ${ }^{2}$ ADITYA K. GUPTA; ${ }^{1}$ DHASARATHAN, P}

\author{
${ }^{1}$ Department of Biotechnology, Prathyusha Institute of Technology and Management, Tiruvallur - 602 025, India. \\ ${ }^{2}$ School of Biotechnology, Madurai Kamaraj University, Madurai - 625 021, India.
}

\begin{abstract}
Salinity and heavy metals affect the growth and development of higher plants and also their productivity. In the present study, Cauliflower (Brassica oleracea var botrytis) seeds were allowed to germinate and grow in the absence (control) and presence of different concentrations (50,100,250,500,750 and $1000 \mu \mathrm{M})$ of $\mathrm{NaCl}, \mathrm{CdCl}_{2}, \mathrm{HgCl}_{2}$ and $\mathrm{ZnCl}_{2}$. Seed germination and growth parameters of seedlings of cauliflower were observed after 5,10 and 15 days of exposure to salinity and heavy metals. In case of salinity, maximum inhibition of seedling growth was observed at $250 \mu \mathrm{M}$ of $\mathrm{NaCl}$ which resulted into $66 \%, 67 \%, 61 \%, 56 \%$ and $25 \%$ inhibition in seed germination, shoot length, root length, fresh weight and dry weight, respectively after 5 days of germination. $\mathrm{NaCl}$ at $500-\mu \mathrm{M}$ concentration and above completely inhibited seed germination. In case of heavy metals, $\mathrm{HgCl}_{2}$ was found to be the most toxic one with $94 \%$ inhibition in seed germination at $250 \mu \mathrm{M}$ concentrations. Shoot length, root length, fresh weight and dry weights were inhibited by $69 \%, 88 \%, 66 \%$ and $71 \%$ respectively, after 5 days of growth in presence of $\mathrm{HgCl}_{2}(250 \mu \mathrm{M})$. On the other hand, only $66 \%$ and $55 \%$ inhibition in seed germination was observed with as high concentration as $1000 \mu \mathrm{M}$ of both $\mathrm{CdCl}_{2}$ and $\mathrm{ZnCl}_{2}$ respectively, after 5 days of seed growth. Further, the extent of reduction in shoot length, root length, fresh weight and dry weight in presence of both $\mathrm{CdCl}_{2}$ and $\mathrm{ZnCl}_{2}$ was found to be less than $\mathrm{HgCl}_{2}$. In general development of root system was severely inhibited in presence of $\mathrm{NaCl}$, $\mathrm{CdCl}_{2}, \mathrm{ZnCl}_{2}$ and $\mathrm{HgCl}_{2}$ at all the concentration tested as evidenced by decrease in root length. Increase in the level of proline accumulation was observed in presence of all heavy metals studied and sodium chloride. @JASEM
\end{abstract}

Keywords: Abiotic stress, salinity, proline and heavy metals.

The responses of plants to environmental stresses have gained great ecological momentum due to their alarming increase in the biosphere, their ultimate environmental fate and the biological magnification of their effect upon entry into human food web. Both abiotic and biotic stresses cause severe limitations in agriculture both quantitatively as well as qualitatively. Biotic stress includes the damage caused by different life forms e.g. pathogens like virus, bacteria, fungi etc., and insects and pests. Abiotic stress refers to the impact of environmental factors like climatic factors, edaphic factors, environmental pollution etc., Salinity and heavy metals in the environment are on the increase, affecting crop productivity. These kinds of stresses have severe impact over the productivity and quality of the plant products. The deleterious effects caused by some of the abiotic factors such as osmotic stress caused by $\mathrm{NaCl}$ and the hazardous effects of the heavy metals and response of plants against such stresses have been well documented (Mathur et al 1987; Wong et al 1988; McCue and Hanson 1990; Saradhi and Saradhi 1991; Bray 1997; Schat et al 1997; Kavi Kishore et al 2005).

Cauliflower is one among the members of the very useful genus Brassica. It is grown worldwide as one of the vegetable crops and has been chosen as the test system for the present study. In the present study, attempts were made to assess the effect of salinity and heavy metals (Cadmium, Zinc and Mercury) on the growth and development of cauliflower seedlings and accumulation of proline under stress.

\section{MATERIALS AND METHODS}

Seeds of cauliflower (Brassica oleracea L. var botrytis cv Early Kunwari) were obtained from
Ottanchatram, Dindigul district in Tamilnadu, India. Growth parameters such as percentage of germination, shoot length, root length, fresh weight and dry weight were measured. Proline content of the seedlings stressed with cadmium, zinc and mercuric chlorides and sodium chloride were estimated according to the procedure of Bates et al., 1973. Tissue sample $(500 \mathrm{mg})$ was ground in liquid nitrogen and extracted with $3 \%$ sulfosalicylic acid. After centrifugation $(10,000 \mathrm{rpm} ; 10$ minutes $)$ the clean supernatant was used to quantify proline. To 2 $\mathrm{ml}$ of the extract, $2 \mathrm{ml}$ of glacial acetic acid and $2 \mathrm{ml}$ of ninhydrin reagent $(2.5 \%$ of ninhydrin in glacial acetic acid and $6 \mathrm{M}$ orthophosphoric acid mixture in a ratio of 6:4) were added and incubated in a boiling water bath for $1 \mathrm{hr}$. Reaction was terminated by placing the tubes on ice. The colour developed was extracted with $4 \mathrm{ml}$ of toluene and read at $520 \mathrm{~nm}$. The amount of proline is calculated from a standard graph. The amount of proline in the sample was expressed in $\mu \mathrm{M}$ [proline]/g fresh weight.

\section{RESULTS AND DISCUSSION}

The responses of plants to environmental stresses have been important to students of agronomy, ecology and physiology ever since the disciplines were first defined. Both abiotic and biotic stresses cause severe limitations in agriculture.

In this study, effect of different concentrations of $\mathrm{NaCl}, \mathrm{CdCl}_{2}, \mathrm{HgCl}_{2}$ and $\mathrm{ZnCl}_{2}$ on seed germination and seedling growth of cauliflower was studied. For this, seeds were allowed to germinate and grow in absence (control) and presence of different concentrations $(50,100,250,500,750,1000 \mu \mathrm{M})$ of $\mathrm{NaCl}, \mathrm{CdCl}_{2}, \mathrm{HgCl}_{2}$, and $\mathrm{ZnCl}_{2}$. Effect of these metal salts was measured by observing seed germination, 
Accumulation of Proline under Salinity.....

shoot length, root length, fresh weight and dry weight after 5, 10 and 15 days of germination. Maximum inhibition of seedling growth was observed at $250 \mu \mathrm{M}$ of $\mathrm{NaCl}$ which resulted into $66 \%, 67 \%, 61 \%, 56 \%$, and $25 \%$ inhibition in seed germination, shoot length, root length, fresh weight and dry weight, respectively, after 5days of germination. $\mathrm{NaCl}$ at $500 \mu \mathrm{M}$ and above concentrations completely inhibited seed germination (Table 1).

Table 1. Effect of Sodium chloride on seedling growth during germination of cauliflower seeds. Seeds were germinated on vermiculite in petriplates in absence (Control) and presence of different concentrations of $\mathrm{NaCl}$ and the frequency of germination, shoot length and root length was monitored on 5, 10 and 15 days of germination (Values are mean of five replicates). ( GM = germination; IN = inhibition; SL = shoot length; RL = root length, $\mathrm{FW}=$ fresh weight; $\mathrm{DW}=$ dry weight)

\begin{tabular}{|c|c|c|c|c|c|c|c|c|c|c|c|}
\hline Days & Conc. $\mathrm{NaCl}(\mu \mathrm{M})$ & $\begin{array}{l}\text { GM } \\
\%\end{array}$ & $\begin{array}{l}\text { IN } \\
\%\end{array}$ & $\begin{array}{l}\mathrm{SL} \\
(\mathrm{cm})\end{array}$ & $\begin{array}{l}\text { IN } \\
\%\end{array}$ & $\begin{array}{l}\mathrm{RL} \\
(\mathrm{cm})\end{array}$ & $\begin{array}{l}\mathrm{IN} \\
\%\end{array}$ & $\begin{array}{l}\text { FW } \\
(\mathrm{mg})\end{array}$ & $\begin{array}{l}\text { \% } \\
\text { IN }\end{array}$ & $\begin{array}{l}\text { DW } \\
(\mathrm{mg})\end{array}$ & $\begin{array}{r}\mathrm{IN} \\
\%\end{array}$ \\
\hline \multirow[t]{5}{*}{5} & 0 & 100 & 0 & 2.62 & 0 & 4.18 & 0 & 29.8 & 0 & 4.0 & 0 \\
\hline & 50 & 65.65 & 32.35 & 1.52 & 41.98 & 3.52 & 15.78 & 24.4 & 18.12 & 3.8 & 5 \\
\hline & 100 & 55.58 & 44.42 & 1.12 & 57.25 & 2.38 & 43.06 & 23.0 & 22.81 & 3.0 & 25 \\
\hline & 250 & 33.82 & 66.18 & 0.84 & 67.93 & 1.60 & 4.72 & 13.0 & 56.37 & 3.0 & 25 \\
\hline & 500 & - & - & - & -- & - & - & - & - & - & - \\
\hline \multirow[t]{5}{*}{10} & 0 & 100 & 0 & 3.90 & 0 & 6.48 & 0 & 69.80 & 0 & 7.0 & 0 \\
\hline & 50 & 67.65 & 32.35 & 2.88 & 26.15 & 4.01 & 38.11 & 41.25 & 40.90 & 5.2 & 25.71 \\
\hline & 100 & 55.58 & 44.42 & 2.50 & 35.89 & 2.60 & 59.87 & 33.64 & 51.80 & 3.6 & 48.57 \\
\hline & 250 & 33.82 & 66.18 & 1.36 & 65.12 & 1.96 & 69.75 & 20.12 & 71.17 & 4.4 & 37.14 \\
\hline & 500 & - & - & - & - & - & - & - & - & - & - \\
\hline \multirow[t]{5}{*}{15} & 0 & 100 & 0 & 4.20 & 0 & 8.11 & 0 & 74.2 & 0 & 11.0 & 0 \\
\hline & 50 & 67.65 & 32.35 & 3.04 & 27.61 & 4.12 & 49.19 & 43.1 & 41.91 & 5.6 & 49.09 \\
\hline & 100 & 55.58 & 44.42 & 2.80 & 33.33 & 2.72 & 66.46 & 37.0 & 49.86 & 3.8 & 65.45 \\
\hline & 250 & - & - & - & - & - & - & - & - & - & - \\
\hline & 500 & - & - & - & - & - & - & - & - & - & - \\
\hline
\end{tabular}

According to McCue and Hanson (1990) the most important factors limiting crop productivity are environmental stresses, of which lack of water (drought) and salinity are the most serious ones. Saline soils inhibit the growth of crop plants because of the effect of water stress, ion toxicity, ion imbalance or a combination of these factors. The extent of reduction in growth is dependent on the species, the salinity level and the ionic composition of the soil.

The inhibitory effect of $\mathrm{NaCl}$ on the growth and germination of seeds of higher plants has been reported by Begum et al. (1992). The deleterious effects of $\mathrm{NaCl}$ on seed germination and growth may be due to osmotic stress, ion toxicities, ion imbalance or the combination of these factors. Similarly, heavy metals also have been shown to affect the growth and development of plant systems. $\mathrm{Cd}, \mathrm{Zn}$ and $\mathrm{Hg}$ are group IIB, rare, non-transition elements. Of the various heavy metals, $\mathrm{Cd}$ and $\mathrm{Hg}$ pose a serious threat to the biosphere. $\mathrm{Cd}$ is readily available to plants from soil, which is polluted. Further the plants do not exclude it during the uptake of essential minerals.

Table 2. Effect of Mercuric chloride on seedling growth during germination of cauliflower seeds. Seeds were germinated on vermiculite in petriplates in absence (Control) and presence of different concentrations of $\mathrm{HgCl}_{2}$ and the frequency of germination, shoot length and root length was monitored on 5, 10 and 15 days of germination (Values are mean of five replicates). ). ( GM = germination; IN = inhibition; $\mathrm{SL}=$ shoot length; $\mathrm{RL}=$ root length, $\mathrm{FW}=$ fresh weight; $\mathrm{DW}=$ dry weight $)$

\begin{tabular}{|c|c|c|c|c|c|c|c|c|c|c|c|}
\hline Days & Conc. $\mathrm{HgCl}_{2}(\mu \mathrm{M})$ & $\begin{array}{l}\mathrm{GM} \\
\%\end{array}$ & $\begin{array}{l}\mathrm{IN} \\
\%\end{array}$ & $\begin{array}{l}\mathrm{SL} \\
(\mathrm{cm})\end{array}$ & $\begin{array}{l}\mathrm{IN} \\
\%\end{array}$ & $\begin{array}{l}\mathrm{RL} \\
(\mathrm{cm})\end{array}$ & $\begin{array}{l}\text { IN } \\
\%\end{array}$ & $\begin{array}{l}\mathrm{FW} \\
(\mathrm{mg})\end{array}$ & $\begin{array}{l}\% \\
\text { IN }\end{array}$ & $\begin{array}{l}\text { DW } \\
(\mathrm{mg})\end{array}$ & $\begin{array}{r}\text { IN } \\
\%\end{array}$ \\
\hline \multirow[t]{4}{*}{5} & 0 & 100 & 0 & 3.06 & 0 & 3.56 & 0 & 30.3 & 0 & 4.3 & 0 \\
\hline & 100 & 33 & 67 & 1.56 & 49.01 & 0.82 & 76.96 & 16.2 & 46.53 & 2.3 & 45.23 \\
\hline & 250 & 6 & 94 & 0.92 & 69.91 & 0.41 & 88.48 & 10.2 & 66.33 & 1.2 & 71.42 \\
\hline & 500 & - & - & - & - & - & - & - & - & - & - \\
\hline \multirow[t]{3}{*}{10} & 0 & 100 & 0 & 4.21 & 0 & 5.18 & 0 & 56.8 & 0 & 7.1 & 0 \\
\hline & 100 & 33 & 67 & 2.08 & 50.09 & 1.12 & 78.37 & 20.3 & 64.26 & 2.7 & 61.97 \\
\hline & 250 & - & - & $*$ & - & $*$ & - & $*$ & - & $*$ & - \\
\hline \multirow[t]{3}{*}{15} & 0 & 100 & - & 5.18 & 0 & 6.23 & 0 & 73.8 & 0 & 10.9 & 0 \\
\hline & 100 & 33 & - & 2.40 & 53.66 & 1.20 & 80.73 & 23.1 & 31.30 & 2.8 & 74.31 \\
\hline & 250 & - & - & $*$ & - & $*$ & - & $*$ & - & $*$ & - \\
\hline
\end{tabular}

In this study an attempt was made to assess the inhibitory effect of heavy metals like $\mathrm{CdCl}_{2}, \mathrm{ZnCl}_{2}$ and $\mathrm{HgCl}_{2}$ on seed germination and seedling growth in cauliflower. Out of $\mathrm{CdCl}_{2}, \mathrm{HgCl}_{2}$ and $\mathrm{ZnCl}_{2}, \mathrm{HgCl}_{2}$ was found to be the most toxic heavy metal with $94 \%$ inhibition in seed germination at $250 \mu \mathrm{M}$ concentration. Shoot length, root length, fresh weight and dry weight were reduced by $69 \%, 88 \%, 66 \%, \&$ $71 \%$ respectively, after 5days of growth in presence of $250 \mu \mathrm{M} \mathrm{HgCl}_{2}$ (Table 2). On the other hand, only 
Accumulation of Proline under Salinity.....

$66 \%$ and $55 \%$ inhibition in seed germination was observed with as high concentration as $1000 \mu \mathrm{M}$ of both $\mathrm{CdCl}_{2}$, and $\mathrm{ZnCl}_{2}$ respectively, after 5 days of germination (Tables 3 and 4). The extent of inhibition in shoot length, fresh weight and dry weight in presence of both $\mathrm{CdCl}_{2}$ and $\mathrm{ZnCl}_{2}$ was found to be less than $\mathrm{HgCl}_{2}$ (Tables 3 \& 4 ). In general, development of root system was severely inhibited in presence of $\mathrm{NaCl}, \mathrm{CdCl}_{2}, \mathrm{HgCl}_{2}$ and $\mathrm{ZnCl}_{2}$ at all the concentrations tested as evidenced by decrease in root length (Tables 1, 2, 3 and 4).

Table 3. Effect of Cadmium chloride on seedling growth during germination of cauliflower seeds. Seeds were germinated on vermiculite in petriplates in absence (Control) and presence of different concentrations of $\mathrm{CdCl}_{2}$ and the frequency of germination, shoot length and root length was monitored on 5, 10 and 15 days of germination (Values are mean of five replicates). ). ( $\mathrm{GM}=$ germination; IN = inhibition; SL = shoot length; RL = root length, FW = fresh weight; DW = dry weight)

\begin{tabular}{|c|c|c|c|c|c|c|c|c|c|c|c|}
\hline Days & Conc. $\mathrm{CdCl}_{2}(\mu \mathrm{M})$ & $\begin{array}{l}\text { GM } \\
\%\end{array}$ & $\begin{array}{l}\text { IN } \\
\%\end{array}$ & $\begin{array}{l}\mathrm{SL} \\
(\mathrm{cm})\end{array}$ & $\begin{array}{l}\mathrm{IN} \\
\%\end{array}$ & $\begin{array}{l}\mathrm{RL} \\
(\mathrm{cm})\end{array}$ & $\begin{array}{l}\text { IN } \\
\%\end{array}$ & $\begin{array}{l}\text { FW } \\
(\mathrm{mg})\end{array}$ & $\begin{array}{l}\% \\
\text { IN }\end{array}$ & $\begin{array}{l}\text { DW } \\
(\mathrm{mg})\end{array}$ & $\begin{array}{r}\text { IN } \\
\%\end{array}$ \\
\hline \multirow[t]{6}{*}{5} & 0 & 100 & 0 & 3.14 & 0 & 3.44 & 0 & 31.8 & 0 & 4.6 & 0 \\
\hline & 100 & 84.3 & 15.7 & 3.02 & 3.82 & 3.36 & 2.32 & 29.6 & 6.91 & 3.2 & 30.43 \\
\hline & 250 & 71.8 & 28.2 & 2.94 & 6.36 & 3.02 & 12.20 & 25.4 & 20.12 & 3.1 & 32.60 \\
\hline & 500 & 62.3 & 37.7 & 2.86 & 8.91 & 2.56 & 25.58 & 24.6 & 22.64 & 3.0 & 34.78 \\
\hline & 750 & 51.0 & 49.0 & 1.82 & 42.03 & 2.28 & 33.72 & 23.2 & 27.64 & 2.8 & 39.13 \\
\hline & 1000 & 33.6 & 66.4 & 1.66 & 47.13 & 1.36 & 60.46 & 18.3 & 42.45 & 2.6 & 43.47 \\
\hline \multirow[t]{6}{*}{10} & 0 & 100 & 0 & 4.64 & 0 & 6.53 & 0 & 64.8 & 0 & 7.2 & 0 \\
\hline & 100 & 84.3 & 15.7 & 3.83 & 17.45 & 3.44 & 46.32 & 50.2 & 22.53 & 5.4 & 25.0 \\
\hline & 250 & 71.8 & 28.2 & 3.46 & 25.43 & 3.32 & 49.15 & 40.8 & 37.03 & 4.8 & 33.33 \\
\hline & 500 & 62.3 & 37.7 & 3.24 & 30.17 & 2.84 & 56.5 & 34.6 & 46.6 & 4.2 & 41.66 \\
\hline & 750 & 51.0 & 49.0 & 3.02 & 34.9 & 2.36 & 63.85 & 30.7 & 52.62 & 3.6 & 50.0 \\
\hline & 1000 & 33.0 & 66.4 & 2.41 & 48.06 & 2.04 & 68.75 & 23.2 & 64.19 & 3.1 & 56.94 \\
\hline \multirow[t]{6}{*}{15} & 0 & 100 & 0 & 5.12 & 0 & 8.21 & 0 & 76.3 & 0 & 13.2 & 0 \\
\hline & 100 & 84.3 & 15.7 & 4.22 & 17.58 & 5.02 & 38.85 & 53.6 & 29.75 & 6.1 & 53.78 \\
\hline & 250 & 71.8 & 28.2 & 3.86 & 24.60 & 3.46 & 57.85 & 43.7 & 42.72 & 5.4 & 59.09 \\
\hline & 500 & 62.3 & 37.7 & 3.30 & 35.54 & 2.38 & 71.01 & 35.3 & 53.73 & 4.4 & 66.66 \\
\hline & 750 & 51.0 & 49.0 & 3.12 & 39.06 & 2.42 & 70.52 & 21.6 & 71.69 & 3.4 & 72.24 \\
\hline & 1000 & $*$ & $*$ & $*$ & - & $*$ & - & $*$ & - & $*$ & - \\
\hline
\end{tabular}

* Plants die within 15 days.

Table 4. Effect of Zinc chloride on seedling growth during germination of cauliflower seeds. Seeds were germinated on vermiculite in petriplates in absence (Control) and presence of different concentrations of $\mathrm{ZnCl}_{2}$ and the frequency of germination, shoot length and root length was monitored on 5, 10 and 15 days of germination (Values are mean of five replicates). ). ( $\mathrm{GM}=$ germination; IN = inhibition; SL $=$ shoot length $; \mathrm{RL}=$ root length, $\mathrm{FW}=$ fresh weight $; \mathrm{DW}=$ dry weight $)$

\begin{tabular}{llllllllllll}
\hline Days & $\begin{array}{l}\text { Conc. } \\
(\mu \mathrm{MnCl})\end{array}$ & $\begin{array}{l}\mathrm{GM} \\
\%\end{array}$ & $\begin{array}{l}\mathrm{IN} \\
\%\end{array}$ & $\begin{array}{l}\mathrm{SL} \\
(\mathrm{cm})\end{array}$ & $\begin{array}{l}\mathrm{IN} \\
\%\end{array}$ & $\begin{array}{l}\mathrm{RL} \\
(\mathrm{cm})\end{array}$ & $\begin{array}{l}\mathrm{IN} \\
\%\end{array}$ & $\begin{array}{l}\mathrm{FW} \\
(\mathrm{mg})\end{array}$ & $\begin{array}{l}\% \\
\mathrm{IN}\end{array}$ & $\begin{array}{l}\mathrm{DW} \\
(\mathrm{mg})\end{array}$ & $\begin{array}{c}\mathrm{IN} \\
\%\end{array}$ \\
\hline 5 & 0 & 100 & 0 & 3.62 & 0 & 4.32 & 0 & 33.6 & 0 & 4.4 & 0 \\
& 100 & 79 & 21 & 3.00 & 17.12 & 3.10 & 28.24 & 29.6 & 11.90 & 3.7 & 15.90 \\
& 250 & 62 & 38 & 2.91 & 19.61 & 2.42 & 43.98 & 25.2 & 25.00 & 3.1 & 29.54 \\
& 500 & 54 & 46 & 2.70 & 25.41 & 1.94 & 55.09 & 24.2 & 27.97 & 3.0 & 31.81 \\
& 750 & 48 & 52 & 2.53 & 30.11 & 1.91 & 55.78 & 23.0 & 31.54 & 3.0 & 31.81 \\
& 1000 & 45 & 55 & 2.22 & 36.51 & 1.73 & 59.95 & 18.2 & 45.83 & 2.8 & 36.36 \\
\hline 10 & 0 & 100 & 0 & 4.71 & 0 & 6.70 & 0 & 61.6 & 0 & 7.0 & 0 \\
& 100 & 79 & 21 & 3.68 & 21.86 & 3.42 & 46.95 & 46.8 & 24.02 & 5.6 & 20.0 \\
& 250 & 62 & 38 & 3.47 & 26.32 & 3.01 & 55.07 & 40.6 & 34.09 & 4.7 & 32.85 \\
& 500 & 54 & 46 & 3.26 & 30.78 & 2.73 & 59.25 & 32.3 & 47.56 & 4.3 & 38.57 \\
& 750 & 48 & 52 & 3.17 & 32.69 & 2.88 & 57.01 & 30.9 & 49.83 & 3.8 & 45.71 \\
& 1000 & 45 & 55 & 2.93 & 37.79 & 2.42 & 63.88 & 27.8 & 54.87 & 3.5 & 50.00 \\
\hline 15 & 0 & 100 & 0 & 5.23 & 0 & 7.46 & 0 & 77.1 & 0 & 12.8 & 0 \\
& 100 & 79 & 21 & 3.83 & 26.76 & 3.46 & 51.20 & 50.6 & 34.37 & 5.8 & 54.68 \\
& 250 & 62 & 38 & 3.80 & 27.34 & 3.37 & 54.82 & 43.1 & 44.09 & 4.9 & 61.71 \\
& 500 & 54 & 46 & 3.31 & 36.71 & 2.88 & 61.39 & 40.5 & 47.47 & 4.5 & 64.84 \\
& 750 & 48 & 52 & 3.28 & 37.28 & 2.42 & 67.56 & 36.2 & 53.04 & 4.1 & 67.96 \\
& 1000 & 45 & 55 & 3.50 & 48.68 & 2.56 & 65.68 & 31.8 & 58.75 & 3.9 & 69.53 \\
\hline
\end{tabular}

The inhibitory effects of heavy metals like $\mathrm{CdCl}_{2}$ $\mathrm{ZnCl}_{2}$ and $\mathrm{HgCl}_{2}$ on the seed germination and seedling growth of higher plants have been known for a long time. Several authors have studied the deleterious effects of Cadmium in several crop sepcies (Indleberg and Wingstrand, 1985; Mathur et al., 1987; Wong et al., 1988).
In nature plants possess some characters either to withstand or evade the stresses. Very specifically it has been demonstrated that plants accumulate osmotic solutes like proline to counteract the effect of salinity and other osmotic stresses. Hence, an attempt has been made to study the accumulation of proline during this stress. For this 10-day-old seedlings were transferred to different concentrations of $\mathrm{NaCl}$, 
Accumulation of Proline under Salinity.....

$\mathrm{CdCl}_{2}, \mathrm{HgCl}_{2}$ and $\mathrm{ZnCl}_{2}$ or water (control). Accumulation of proline was monitored after $15 \mathrm{hr}$ of transfer. Sodium chloride induced accumulation of proline seems to be concentration dependent. More than two-fold increase in the accumulation of proline was noticed when seedlings were transferred to $100 \mu \mathrm{M} \mathrm{NaCl}$ for 15 hours whereas the level of proline rose up to six-fold at $1000 \mu \mathrm{M} \mathrm{NaCl}$ (Figure $1)$.

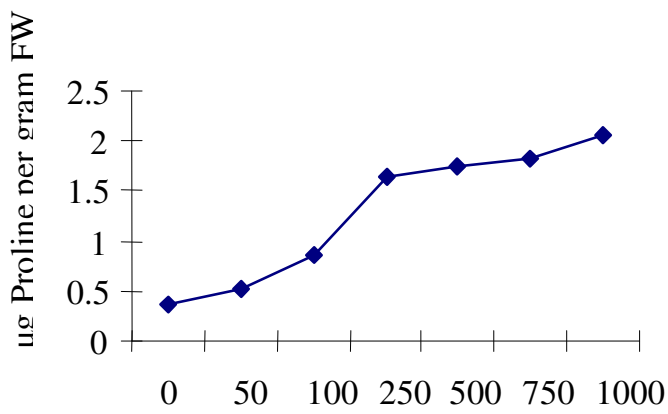

Concentration of $\mathrm{NaCl}(\mu \mathrm{M})$

Fig 1: Accumulation of proline in 10 - day - old seedlings grown in presence of $\mathrm{NaCl}$.

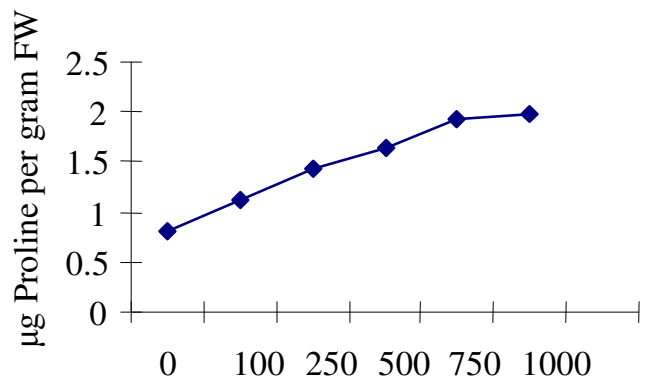

Concentration of $\mathrm{CdCl}_{2}$

Fig 2: Accumulation of proline in 10 - day - old seedlings grown in presence of $\mathrm{CdCl}_{2}$

Likewise the impact of other heavy metal salts over the accumulation of proline was also studied. Increase in the level of proline accumulated was observed in presence of all heavy metals studied. The level of proline accumulated is two times more than the control in seedlings stressed with $250 \mu \mathrm{M} \mathrm{CdCl}_{2}$ for 15 hours. The accumulation of proline was concentration dependent (Figure 2). Zinc Chloride also has similar effect over the accumulation of proline in stressed seedlings. There appears to be nearly two-fold increase in proline accumulated after 15 hours in seedlings treated with $500 \mu \mathrm{M} \mathrm{ZnCl}_{2}$, compared to control. $\mathrm{ZnCl}_{2}$ also exhibited a concentration dependent pattern of accumulation proline (Figure 3 ). $\mathrm{HgCl}_{2}$ is the most toxic one of the three heavy metals studied. It resulted in a significant level of proline accumulated after $15 \mathrm{hr}$ of incubation. The level of proline accumulation doubled in $500 \mu \mathrm{M}$ $\mathrm{HgCl}_{2}$ treated seedlings compared to control (Figure 4).

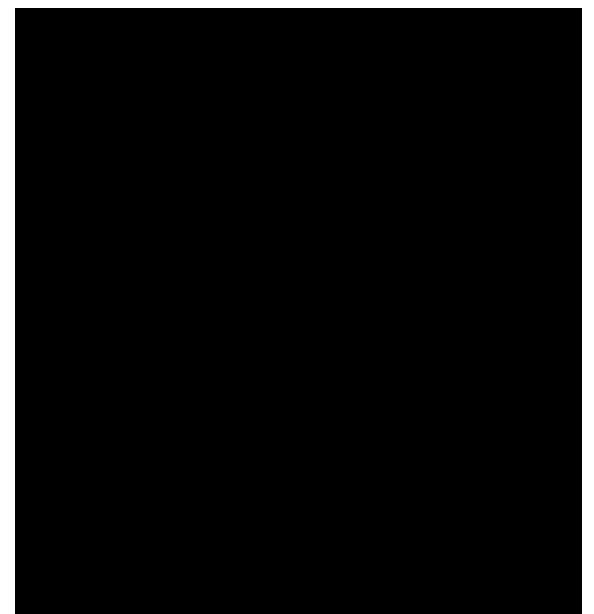

Fig 3: Accumulation of proline in 10 - day - old seedlings grown in presence of $\mathrm{ZnCl}_{2}$ 


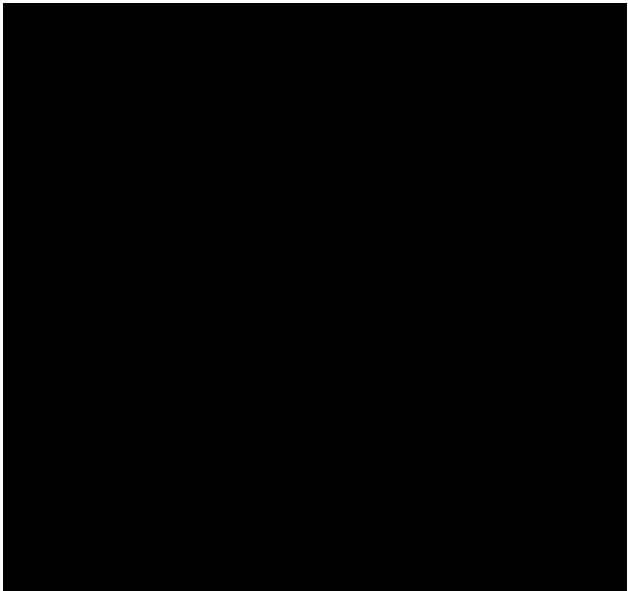

Fig 4: Accumulation of proline in 10 - day - old seedlings grown in presence of $\mathrm{HgCl}_{2}$

Many eubacteria, algae and higher plants accumulate free proline in response to osmotic stress (Dealaeny and Verma 1993), a phenomenon first observed by Kemble and MacPherson (1954) in wild rye grass. Accumulation of proline under different stresses and the advantage conferred by higher level of proline to tolerate such stresses have been discussed by several researchers (Saradhi et al 1991; Saradhi and Saradhi, 1991; Girousse et al 1996; Bray 1997; Anoop and Gupta 2003; Kavi Kishore et al 2005).

Conclusion: It has been observed in the present study that $\mathrm{NaCl}, \mathrm{ZnCl}_{2}, \mathrm{CdCl}_{2}$ and $\mathrm{HgCl}_{2}$ have adverse impact on the growth and development of cauliflower seedlings as evidenced by their impact on seed germination, shoot/root length and fresh/dry weight. Sodium chloride induced accumulation of proline to a significant level after 15 hours. Similarly, accumulation of proline was observed in all the concentration of heavy metals tested. Accumulation of proline may be a stress-induced response and over producing proline may confer tolerance to crops against these stresses.

Acknowledgement: A research fellowship to PT from CSIR, New Delhi is gratefully acknowledged.

\section{REFERENCES}

Anoop, N., Gupta, A.K., 2003. Transgenic indica rice cv IR-50 over-expressing Vigna aconitifolia delta(1)pyrroline-5-carboxylate synthase cDNA shows tolerance to high salt. J.Plant Biochem. Biotechnol. 12, 109-116.

Bates, L. S., Waldren, R. P., Teare, I. D., 1973. Rapid determination of free proline for water-stress studies. Plant and Soil 39 (1), 205-207.
Begum, F., Karmoker, J.L., Fattah, Q.A., Moniruzzaman, A.F.M., 1992. The effect of salinity on germination and its correlation with $\mathrm{K}+, \mathrm{Na}+, \mathrm{Cl}^{-}$accumulation in germinating seeds of Triticum aestivum L. cv. Akbar. Plant Cell Physiol. 33, 1009-14.

Bray, E.A., 1997. Plant Responses to water deficit. Trends Plant Sci. 2, 48-54.

Delaney, A.J., Verma, D.P.S., 1993. Proline biosynthesis and osmoregulation in plants. Plant J. 4, 215-223.

Griousse, C., Bournville, R., Bonnemain, J-L., 1996. Water deficit induced changes in concentrations in proline and some other aminoacids in the phloem sap of alfalfa. Plant Physiolol. 111, 109-113.

Iindberg, S., Wingstrand, G., 1985. Mechanisms for Cd2 + inhibition of $(\mathrm{K}+\mathrm{Mg})$ ATPase activity and $\mathrm{K}+(\mathrm{MRb}+)$ uptake in roots of sugar beet (Beta vulgaris). Physiologia Plantarum 63, 181-186.

Kavi Kishor, P.B., Sangam, S., Amrutha, R.N., Laxmi, P.S., Naidu, K.R., Rao, K.R.S.S., Rao, S., Theriappan, P., Sreenivasulu, N., 2005. Regulation of proline biosynthesis, degradation, uptake and transport in higher plants: Its implications in plant growth and abiotic stress tolerance. Current science, 88 (3), 424-438.

Kemble, A. R., Macpherson, H. T., 1954. Liberation of Amino Acids in Perennial Rye Grass during Wilting. Biochemical J. 58, 46.

Mathur, K.C., Srivastava, R.K., Chaudhary, K., 1987. Effect of $\mathrm{Cd}$ and $\mathrm{Cr}$ metals on germination and early growth performance of Allium cepa seeds. Proc. Nat. Acad. Sci. India. Sect. B (Biol. Sci.). 57, 191-196.

McCue K.F., Hanson, A.D., 1990; Drought and salt tolerance: towards understanding and application. Trends Biotechnol. 8, 358-362.

Saradhi, A., Saradhi, P.P., 1991. Proline accumulation under heavy metal stress. J. Plant Physiol. 138, 554-558.

Saradhi, A., Saradi, P.P., Mohanty, P., 1991. Proline enhances primary photochemical activities in isolated thylakoid membranes of Brassica juncea by arresting photoinhibitory damage. Biochem. Biophys. Res. Commun. 181: 1238-1244.

Schat, H., Sharma, S.S., Voojis, R., 1997. Heavy metal induced accumulation of free proline in a metal-tolerant and a non-tolerant ecotype of Silene vulgaris. Physiol. Plant. 101, 477-482.

Wong, Y.S., Lam, H.M., Dhillon, E., Tam, N.F.Y., Leung, W.N., 1988. Physiological effects and uptake of cadmium in Pisum sativum. Environmental International $14,535-543$. 